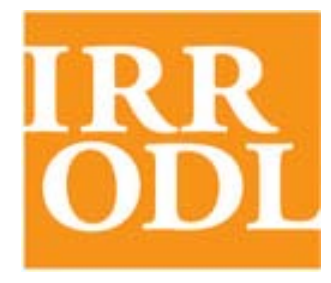

International

Review of

Research in Open

and Distance

Learning

Vol. 12.1

January -2011

\section{Dwell in Possibility: PLAR and $e$ - Portfolios in the Age of Information and Communication Technologies}

Judith O. Brown

Barry University, USA

\begin{abstract}
Emily Dickinson wrote, "I dwell in Possibility-A fairer House than ProseMore Numerous of Windows-Superior-for Doors” (Johnson, 1961, p.657). Dickinson's simple yet profound reference to the expansive nature of poetry over prose may be taken as a metaphor for the possibilities of information and communication technologies (ICTs) over written modes of expression. Whether we identify with this analogy or not, what we can say today with some certainty is that the advent of ICTs has impacted prior learning assessment and recognition (PLAR) by expanding the potential for knowledge acquisition, expression, and delivery.
\end{abstract}

The purpose of this article is to examine the potential of experiential learning eportfolios to promote connections between several different types of learning academic, workplace, and web-based. The author contends that this type of PLAR enables undergraduate adult learners to not only articulate and equate experiential learning to academic knowledge but also, and most importantly, to demonstrate knowledge visually and audibly through the utilization of ICTs. Two pilot case studies of e-portfolio development are described to support the author's position.

Keywords: Prior learning assessment and recognition; PLAR; information and communication technologies; experiential learning; e-portfolios, adult learners 


\section{Introduction}

The experiential learning portfolio in adult higher education, unlike the academic or teaching portfolio, is a purposeful compilation of document-supported descriptions of learning outcomes acquired from professional and personal experiences (Brown, 2005). Paper media experiential learning portfolios have been utilized in the United States in adult undergraduate programs since the late 1960s (Michelson \& Mandell, 2004). Currently, over 1,000 colleges and universities in the USA (Flint et al., 1999) offer portfolios as a method of PLAR. Portfolios are also prevalent in adult higher education in Canada, Great Britain, Australia, the European Union, and South Africa (Evans, 1999; Osmam, 2003). Portfolios may satisfy entrance or college credit requirements. The learner evaluates and documents learning from real-world settings and equates it to academic knowledge gained in higher education. Faculty evaluators assess students' assertions of learning and determine credit awards.

In the last quarter of the $20^{\text {th }}$ century, the advent of the age of information has profoundly influenced how and where we learn. Fueling this period was the introduction of ICTs, which have had a tremendous impact on the sources and expression of learning and on educational delivery systems. As Dinevski and Psunder (2005) pointed out, "a school [and a workplace] is not separated from the system of societal values of its period” (p. 394). In their position paper, they summarized the new learning processes influenced by ICTs that have emerged in the last thirty years as representing the following shifts:

- from linear to hypermedia learning,

- from instruction to construction and discovery,

- from teacher-centered to learner-centered education,

- from absorbing material to learning how to navigate and how to learn,

- from school to lifelong learning,

- from one-size-fits-all to customized learning, and

- from the teacher as transmitter to the teacher as facilitator. (p. 395)

Experiential learning e-portfolios (ELEPs) attend to many of the new processes and social values of this new era by allowing adult students not only to capture learning from multiple venues (e.g., educational institutions, work, web-based, and community learning) but also in a variety of multimedia modalities (e.g., audio, digital photos, video). One of the unique features of ELEPs is that they demonstrate learning by using multimedia as well as the written word. Additionally they share the following features of hard copy portfolios:

- facilitating learner-constructed education,

- integrating practice with content-knowledge and theory, and

- promoting reflection and self-evaluation. 
Since the mid-1990s, e-portfolios have been utilized increasingly by traditional-age students ${ }^{1}$ to express learning through the utilization of various software programs, the inclusion of hyperlinks, the reference to blogs, wikis, and social networking sites, and the insertion of digital photos and videos. Noteworthy is an e-portfolio created by a Pennsylvania State University undergraduate majoring in meteorology who not only wrote about his learning from various courses but also inserted a video clip of himself giving the weather on the college's TV station. These processes underscore the changing nature of articulating learning in the age of ICTs. In the last five years, PLAR experiential learning e-portfolios have gained limited recognition among adult educators. The author argues that this mode of PLAR may augment adult learners' ability to demonstrate learning, to increase creativity, and to advance ICT skills, as well as to uncover tacit learning that is equivalent to college-level learning.

\section{Theoretical Perspectives}

It is well established in the literature that individuals learn in a multitude of places and ways. Since the late $19^{\text {th }}$ century, psychological studies and scientific research on brain function have delineated multiple theories on how we learn. In the last three decades, precepts on adult and lifelong learning underscored the need for different modes of expression within college degrees for this population, now well over $50 \%$ of undergraduates. Thus, the experiential learning portfolio, as noted previously, became increasingly popular as a component of degree programs designed for adults beginning or returning to college.

\section{Constructivism}

Some credit Piaget as the father of constructivist thought whereby "the individual mentally constructs the world of experience” (Gergen, 1999, p. 236). Social constructionists agree; however, they purport that the construction of the worldview is done so with "categories supplied by social relationships... thereby opening a new range of possibilities” (p. 237).

Gergen points out in his seminal text, An Invitation to Social Construction, that "the constructionist dialogues contain enormous potential; they open new spans of possibility for creating the future. This is so in the intellectual/scientific world, in professional practice and our daily lives” (pp. 4-5). Here we have the connections between different types of learning that led Gergen to note that because of the constructionist critique of traditional modern concepts of the world "we begin to locate alternative visions of knowledge, truth, and self ... We do not lose the old traditions of study, but rather through constructionism we add significantly to the human science inquiry” (p. 5).

\footnotetext{
${ }^{1}$ See Helen Chen's site at http://scil.stanford.edu/about/staff/bios/chen.html for portfolio projects at Stanford University and Penn State University's site on academic e-portfolios at http://portfolio.psu.edu/.
} 
Gergen, as others, promote a holistic vision of learning that does not abandon the familiar yet embraces the possibilities of the new. PLAR and e-portfolios are $21^{\text {st }}$-century expressions of the "new."

\section{Transforming Experiences to Learning}

While there are several models on how experiences are transformed into learning, David Kolb's four-stage model (Kolb, 1984; Baker \& Kolb, 1990), based on the precepts of Dewey, Piaget, and Lewin, is most frequently used in PLAR experiential learning portfolio programs to explain this phenomenon. The stages, while presented in a linear fashion, often involve a circuitous pattern in actual practice.

The model consists of four stages.

- Stage 1: Concrete experience - the learner's focus is on being involved in experiences and dealing with immediate human situations in a personal way.

- Stage 2: Reflective observation - the learner's focus is on understanding the meaning of ideas and situations by carefully observing and impartially describing them.

- Stage 3: Abstract conceptualization - the learner's focus is on using logic, ideas, and concepts to form generalizations and theories about the experience.

- Stage 4: Active experimentation - the learner's focus is on actively influencing people and events by testing and applying the resulting concepts in new situations. (Baker \& Kolb, 1990)

Kolb's model implies - and others agree - that no experience, whether in the classroom, in the workplace, or on the Web, can become a learning experience without critical reflection, analysis, and evaluation (Brown, 2000; Boud, 1998; Sheckley \& Keeton, 2001). The portfolio, in general, is designed to enable students to make the often hidden learning in the workplace and the community explicit through the aforementioned processes. It challenges performance-based-only assessments to value reflection on and in practice (Argyris \& Schön, 1978; Marsick, 1990; Mezirow, 1996; Schön, 1983).

\section{Workplace Learning}

In today's workplace, adult learners must not only continuously increase their knowledge base but also be able to use it in new situations and environments (Artino, 2008). Identifying learning during portfolio development from concrete experiences that are related to theoretical concepts provides students with a combination of theory and practice that may serve them well throughout their lives. For example, a learner in the accounting field may be able to express how he or she used the principles of the field by transferring them from one company to another during the course of a career. Thus, experience and intellectual prowess can produce a more holistic, balanced form of learning than either alone. Over the last two decades, the workplace and the greater community have gained recognition as important sites of learning by recognizing the 
interplay of practice and theory (Billet, 2008; Tynjala, 2008; Boud, 1993; Ellstrom, Ekholm, \& Ellstrom, 2008).

Similar to Gergen's social constructionism and the situated learning ideas of Choi and Hannafin (1995), Lave and Wenger's (1991) work on communities of learning in the workplace and elsewhere expanded ideas on learning as situated in actions and inextricably connected to the social environment where it is acquired. Since a great deal of an individual's life is spent at work and in the community-at-large rather than in the classroom, it is plausible to consider these venues as important sources of learning. This is underscored by the dilemma of many organizations faced with losing a large portion of their workforce to the retirement of the baby boom generation. How does an institution garner the large amount of tacit knowledge that will disappear with these retirees? One answer is to develop e-portfolios based on workplace learning experiences whereby employees can uncover and demonstrate through audio and visual guides what they have learned over decades of employment thus leaving a library of e-portfolios ready for use by new workers.

\section{E-Learning}

In the era of Web 2.0, the construction of knowledge by individuals and groups through wikis, blogs, folksonomies, mash ups, and so on, and the personalization of information for social networking (YouTube, MySpace, and Facebook) are ubiquitous. Consequently, the need to recognize new ways of creating and sharing information through formal and informal education has never been greater. For adult learners, the experiential learning e-portfolio recognizes the importance of out-of-class learning experiences by promoting connections among different learning environments. The inclusion of blogs and wikis in e-portfolios enrich the expression of experiential learning just as they do in classroom learning.

Countries in the European Union are excited about learning acquired from web-based arenas. They regard the development of e-portfolios as critical economic and lifelong learning tools for all EU members. Torhild Slaatto at the Norwegian Association for Distance Education notes that the EU is excited about the utilization of e-learning and e-portfolios for students and citizens alike. He quotes the European Institute for E-Learning's (EifEL) definition of e-portfolios in a paper he presented at the European Distance and E-Learning Network Conference in Helsinki, Finland, in 2005:

An e-portfolio is a personal digital collection of information describing and illustrating a person's learning, career, experience and achievements ... Technology has rejuvenated the concept of personal portfolios, which are now increasingly being seen as a powerful tool for personal development. The interest of a digital or electronic portfolio resides in its multiple dimensions: it is at the same time a tool for learning and a tool for assessment. In the context of a knowledge society, where being information literate is critical, the portfolio can provide an opportunity to 
demonstrate [italics mine] one's ability to collect, organize, interpret, and reflect on documents and sources of learning. (Slaatto, 2005, p. 147)

\section{Method}

Two case studies of the e-portfolio pilot programs are presented in this section. The pilot program team sought to discover if the e-portfolio format increased the creativity and technical skills of adult learners in addition to the professional and personal learning articulated and documented in paperbased portfolios.

\section{Setting}

Barry University's School of Adult and Continuing Education (ACE) employs a variety of strategies to help nontraditional-age students balance the demands of family, work, and undergraduate degree completion. ACE was designed to serve adult learners in a manner similar to other undergraduate programs with a large portion of nontraditional-age students. This was accomplished by offering night and evening classes, a host of standardized test-out examinations, and a thorough portfolio evaluation. Since ACE's inception in the mid-1970s, portfolios have been a major component of degree completion for over $80 \%$ of the school's student body.

In 2005, ACE's portfolio department decided to pilot an e-portfolio model. The intent was to encourage adult learners to go beyond paper media in the expression of experiential learning. Administrators and faculty engaged in the portfolio process wanted to explore the potential of experiential learning e-portfolios to augment the connections between academic, workplace, and web-based learning by allowing learners to communicate what they know and also to demonstrate how they know it.

Members of the department hypothesized that through the utilization of various software programs and by going beyond the written word, students would have the opportunity to increase critical thinking, creativity, and ICT competencies. They proposed that these additional modes of expression could enhance PLAR in the high-tech era by employing PowerPoint designs, by hyper-linking to Web sites, by inserting pictures, and by streaming videos in portfolios. It took approximately nine months to create the policies and materials for the first pilot. A technical manual and sample e-portfolio were developed and bi-monthly meetings of the ELEP team produced participation criteria, incentives, and recruitment guidelines.

\section{The First Pilot Study}

In the first pilot study, 30 adult learners with a variety of academic majors, who were in geographic proximity to each other in order to attend three face-to-face technical development workshops and who met a set of criteria (see Table 1), were solicited to create experiential learning e-portfolios. Out of the 30, 12 students accepted the invitation to participate. They 
attended a face-to-face portfolio seminar and three workshops over a two-month period to gain an understanding of the various sections of an experiential learning portfolio. Then the participants attended two-hour technical workshops every three weeks over the next four months where they learned software and other applications in order to transform their paper-based portfolios into eportfolios.

The main components of their e-portfolio consisted of

- a PowerPoint presentation;

- a navigation bar to the various sections of the portfolio, so faculty evaluators could go from one section to another;

- a series of hyperlinks to the Internet that highlighted organizations and community activities where students gained learning experiences;

- an area of scanned documentation that supported students' learning claims; and

- an opportunity to insert digital photographs and streaming video to underscore learning.

ACE's e-portfolios were not posted on the Web though they contained hyperlinks to relevant Web sites. Rather they were burned on CD ROMs or DVDs for faculty assessment to avoid possible technical problems or unwarranted display of confidential information using the University’s server during evaluation.

\section{Table 1}

Criteria for Participation and Incentives

\begin{tabular}{|c|c|}
\hline Pilot 1: Criteria for participation & Pilot 1: Incentives \\
\hline $\begin{array}{l}\text { 1. Participants have been fully accepted and are } \\
\text { enrolled in ACE courses. }\end{array}$ & $\begin{array}{l}\text { 1. Participants will be given an } \\
\text { incentive of } \$ 300 \text { off their portfolio } \\
\text { administrative fee if they submit an } \\
\text { e-portfolio in the designated } \\
\text { timeframe. }\end{array}$ \\
\hline $\begin{array}{l}\text { 2. Participants have completed English } 329 \text { with a } \\
\text { grade of } \mathrm{C} \text { or better, or have successfully passed } \\
\text { the English placement/test-out exam. }\end{array}$ & $\begin{array}{l}\text { 2. Participants will increase the body } \\
\text { of knowledge on e-portfolio } \\
\text { development. }\end{array}$ \\
\hline $\begin{array}{l}\text { 3. Participants are in good academic standing } \\
\text { (cumulative GPA of } 2.0 \text { in all Barry University } \\
\text { course work). }\end{array}$ & $\begin{array}{l}\text { 3. Participants will interact with an IT } \\
\text { professor who will support them } \\
\text { during the e-portfolio process. }\end{array}$ \\
\hline $\begin{array}{l}\text { 4. Participants can document five years of } \\
\text { professional work experiences and/or } \\
\text { community activities. }\end{array}$ & $\begin{array}{ll}\text { 4. Participants will receive a set of } \\
\text { instructional materials designed } \\
\text { solely for e-portfolio development. }\end{array}$ \\
\hline $\begin{array}{l}\text { 5. Participants are willing to fill out pre- and } \\
\text { post-surveys and participate in a recorded } \\
\text { post-submission focus group. }\end{array}$ & $\begin{array}{l}\text { 5. Participants will have additional } \\
\text { advisor support during the } \\
\text { development process. }\end{array}$ \\
\hline $\begin{array}{l}\text { 6. Participants will attend a portfolio seminar in } \\
\text { the summer session. }\end{array}$ & \\
\hline 7. Participants will attend six face-to-face & \\
\hline
\end{tabular}




\begin{tabular}{|c|c|}
\hline portfolio workshops. & \\
\hline $\begin{array}{l}\text { a. Summer and fall: Development } \\
\text { workshops held in Merritt Island } \\
\text { and Orlando. }\end{array}$ & \\
\hline $\begin{array}{l}\text { b. Fall: Technical workshops held at } \\
\text { Merritt Island only. }\end{array}$ & \\
\hline $\begin{array}{l}\text { 8. Participants will submit ELEP in spring A or } \\
\text { spring B sessions. }\end{array}$ & \\
\hline $\begin{array}{l}\text { 9. Participants will submit ELEP on CD-ROM or } \\
\text { DVD. }\end{array}$ & \\
\hline $\begin{array}{l}\text { 10. Participants are willing to sign a letter of } \\
\text { commitment/consent with no penalties for not } \\
\text { completing. }\end{array}$ & \\
\hline $\begin{array}{l}\text { 11. Participants will grant permission to use their } \\
\text { ELEP as a model for other students. }\end{array}$ & \\
\hline Pilot 2: Criteria for participation & Pilot 2: Incentives \\
\hline $\begin{array}{l}\text { 1. All of the above and completion of } \\
\text { Computer Science } 102 \text { and workshop } \\
\text { attendance will be online through } \\
\text { Blackboard. }\end{array}$ & $\begin{array}{l}\text { 1. All of the above, except no } \\
\text { reduction of portfolio administrative } \\
\text { fee. }\end{array}$ \\
\hline
\end{tabular}

\section{Data collection.}

The first group of participants was given pre- and post-test surveys (see Appendix A). They also participated in a focus group following submission of their e-portfolios. Their survey responses were compiled as descriptive statistics in MS Excel and analyzed in a comparative manner (see Appendix B and C). The major comments of the focus group and faculty evaluator are also described in the Results section of this paper.

\section{The Second Pilot Study}

In January 2007, a second pilot program was launched. This time a system-wide approach was initiated as ACE has 18 educational sites throughout the state of Florida. Nine students throughout ACE's state-wide system agreed to participate in e-portfolio development. Due to the distance between ACE sites, face-to-face sessions for technical support were eliminated. Instead, online Blackboard tutorials with voice-overs and professor support through e-mail and telephone (if needed) were offered. Moreover, the second pilot study's participants had to have completed introductory software application courses that covered PowerPoint, hyper-linking, folder creation, and scanning of documents. Thus, by selecting adult learners who had a basic understanding of ICTs, we strove to mitigate concerns noted in the first group's comments about the additional time needed to learn software programs. Moreover, while criteria 1-4 and 9-11 were followed by the second study's participants, only incentives 2-5 were offered to them. 


\section{Data collection.}

Students' post-test surveys were collected and analyzed by the ELEP team (see Appendix D). As in the first pilot, there were no issues of confidentiality or anonymity as all the students agreed to share their e-portfolios with other students. From the ELEP team's analysis of the participants' comments, no further revisions were required of the program delivery and materials before system-wide implementation could be offered to all ACE students, which was done in 2008.

\section{Results}

Ten students completed the first pilot, which ended in 2006. Findings from the focus groups and pre- and post-surveys (see Appendix B and C) of the students indicated that the creation of an eportfolio significantly augmented (by 10\%, 20\%, 30\%, 40\%, and in some areas 60\%) their technical skills while increasing academic competencies (10\% to 40\%) and assessment of professional/workplace learning (10\% primarily to $30 \%$ ). Thus, in every survey question category, learners indicated an increase in "strongly agree/agree" in all three areas of learning. However, in the focus group discussion, most of the pilot participants found the e-portfolio development process compounded their academic workload; learning how to transform a paper portfolio into an e-format proved challenging and time consuming. To paraphrase the comments of nine of the ten participants: "I never thought it would take so much time to learn how to create file folders, navigation bars, and the other e-portfolio features. I might not have participated if I knew this beforehand.” In spite of this complaint, the participants overwhelmingly agreed that they increased their technical, personal, and professional competencies as a result of e-portfolio development.

The second pilot was completed in the fall of 2008. Five students developed an e-portfolio. However, only three participants completed a questionnaire on suggestions for the improvement of online tutorials and guidance materials. Even with this limitation, the participants described their learning from the e-portfolio process with enthusiasm (see Appendix D). Overall, participants were pleased with their increased ICTs in the expression of their workplace-based experiential learning. Most important, in addition to their increased recognition of their learning outside of the academy, they also augmented their technology skills and demonstrated learning through a high-tech format. The option to develop an e-portfolio is now available to all adult learners at ACE.

\section{Faculty Views of Pilot e-Portfolios}

Faculty evaluators recognized the potential of e-portfolios to connect academic, workplace, and high-tech learning; however, as with students, they had to adjust to the learning curve created by the use of ICTs and spent more time than normal on the evaluation process. It follows then that faculty perceptions of e-learning and e-portfolios are a vital component of how colleges and universities address learning in the era of ICTs and the Internet. Faculty who commented on eportfolio evaluations during the pilot programs, even those who taught programs in information 
technology, were wary of the authenticity of scanned documents in the e-portfolios as compared to viewing original documents in paper portfolios. In order to mitigate this problem, portfolio intake staff (all student portfolios, especially documentation, must be signed off by the school's portfolio intake staff) included a written document with the e-portfolios verifying seeing original documents that were scanned. Learning how to navigate e-portfolios and problems with different levels of the software program utilized by the students and the evaluators were other issues that concerned faculty evaluators. Researching faculty views on PLAR portfolios in general, and eportfolios in particular, would be advisable as student use of ICTs increases.

\section{Discussion}

As shown elsewhere (Brown, 2002; Brown, McCrink, \& Maybee, 2004; Mandell \& Michelson, 2004; Timmons, 2008), PLAR portfolios hold the promise of learning outcomes beyond the identification of prior learning for college credit. Critical thinking and communication competencies may be augmented from the development process itself and reveal patterns of individual and career development over the lifespan.

Even in this limited study, it appears that the creation of an e-portfolio further supports the many ways and places in which individuals learn: through critical reflection on experiences; by scaffolding and building on experiences; within the social context in which it occurs; by deconstruction and reconstruction; and in workplaces, on the Web, in classrooms, and in the world at large. Moreover, e-portfolios have the potential to connect one's diverse learning experiences and environments throughout one's life through demonstration in a digital format accessible to others worldwide. Surely, the age of ICTs has no less an impact on humanity than the invention of the printing press. For as Dickinson wrote in her expansive vision, "Of Chambers as the Cedars-Impregnable of Eye-And for an Everlasting Roof - The Gables of the Sky" (Johnson, 1961, p. 657). Dickinson's image of the extensive sky is appropriate for the ever broadening capabilities of PLAR e-portfolios to facilitate knowledge acquisition and expression. Two other institutions of higher learning, one in the USA and one in the UK, underscore this perspective.

\section{Rose-Hulman Institute of Technology}

A 2008 article by Paul Basken in The Chronicle of Higher Education detailed the transformative effects of an e-portfolio system instituted at Indiana's Rose-Hulman Institute of Technology. Basken quotes colleague Barbara Cambridge, who states, "Electronic portfolios are a way to generate learning as well as document learning” (p. A30). For administrators like Cambridge, the portfolio system is valued for its ability to produce "excellent information about what students are learning and how well... [and to see] how effectively the college is teaching ... skills and to revise its approach as necessary" (p. A30). This increases the school's ability to meet its mission and to promote college-wide accountability. Students also value e-portfolios as mechanisms to reach prospective employers in a high-tech format. 


\section{Open University, UK}

Herman and Kirkup (2008) produced an interesting study on the use of e-portfolios for mature students returning to employment in the science, engineering, and technology sectors. They studied 113 female students who were enrolled in a short online course that offered training in the development of an e-portfolio to replace the usual CV as they prepared "to re-enter the workforce after a career break" (p. 67). The course also allowed the participants an opportunity to engage in personal and professional development planning. Seventy-six of the participants completed the course, and 47 returned questionnaires on their e-portfolio experience. Ten telephone interviews, 16 critical incident e-mails, and 19 online discussion postings were also utilized in the data collection.

The results for this group indicated overwhelmingly that the benefits of reflection, critical thinking, and self-assessment inherent in the creation of experiential learning e-portfolios outweighed any problems they experienced with the Profile application they utilized. Additionally, the personal record of achievement contained in the e-portfolio was more useful than a CV. In this case, the creation of an easy-to-update e-portfolio served as a professional development tool motivating learners to re-enter the workforce with increased confidence in their capabilities.

The importance of recognizing learning, no matter where or how it takes place, is a necessity in today's knowledge-based world. Yet, while the expansive nature of the Web beacons to many, it is important to note that critical thinking plays an important role in discerning web-based knowledge and learning from the ever-expanding sources and amount of information individuals are exposed to on a daily basis. Keeping in mind this caveat, it has become increasingly evident in this high-tech age that "change is now so great and so far reaching that no amount of education during youth can prepare adults to meet the demands that will be made on them” (Cross, 1991, p. vi). Consequently, "adult and lifelong learning represent a more and more essential part of ...traditional educational institutions” (Scuzs \& Bo, 2005, p. i). Learning does not begin or end within formal educational institutions (Cross, 1991).

Accordingly, it is incumbent on the academy to continue to explore novel ways to acknowledge a broad concept of and approach to teaching and learning. Sometimes referred to as the digital notebook, the e-portfolio allows learners to trace the development of their thinking and learning over time and to show those competencies to the university and to employers (Maloney, 2007). By its very nature, a portfolio deconstructs barriers between workplace and university learning while maintaining each setting's unique contribution to lifelong learning. Portfolio development requires adult learners to reflect on, analyze, evaluate, and equate their experiential learning to academic knowledge, thus encouraging the connection between practice and theory in the process. While hard-copy portfolios demonstrate competencies and skills, the e-portfolio encourages students to go a step further and exhibit these in a richer format than narrative alone by incorporating multimedia (ICTs). 
The promotion of continuity between academic, workplace, and web-based learning is critical in today's world. As the sponsors of the European Distance and E-Learning Network International Conference (EDEN) wrote in their introductory conference remarks:

E-learning is evolving, like the world around us. The relationship between learning, working and the rest of life is also subject to profound changes. . . . There is an ever stronger need for the validations of the visions, for the conceptualizations of the results available, for the credible "demonstration of the possible.” ... The traditional education systems and settings are changing slowly. Together with visionaries and the sociotechnical forerunners, an important role remains with the progressive practitioners, who investigate, develop, experiment with new solutions and deliver proofs of good practice in elearning. (EDEN, 2007)

The self-inventory process of portfolio development in general, and the demonstration of knowledge facilitated by e-portfolios in particular, produces a powerful tool that promotes connections between academic, workplace, and web-based learning by exhibiting the unique talents of the learner. Unfortunately, in many higher education institutions, the emphasis is on what types of new learning academic and teaching e-portfolios may produce rather than recognizing the possibilities that prior learning portfolios in an e-format may produce.

\section{Conclusions}

Reading a book, seeing a play, and listening to music are three very different media experiences, each with a unique dynamic and impact on the human psyche. The same can be said when comparing the development of a paper experiential learning portfolio with the development of an e-portfolio. What both have in common is the gaining of personal and professional learning outcomes from the process itself (e.g., communication, organization, and self-knowledge), beyond the reflection, identification, analysis, evaluation, and articulation of prior learning from non-academic venues (Brown, 2000; Brown, 2002). In the case of the e-portfolio, the use of multimedia, such as photos, videos, hyperlinks, and other ICTs, has the potential to present a different dynamic to the expression of experiential learning. "[It] is just one model for thinking about how technology can enhance teaching and learning” (Maloney, 2007, p. 27B).

As PLA portfolios become an increasingly valid mechanism in assessing learning, it is hoped that adult educators will encourage learners to use e-portfolios as an additional tool to

- demonstrate their technical skills, professional and personal competencies,

- incorporate visual and audio validation of prior learning,

- create new designs with software programs,

- augment reflection, creativity and communication, and

- evaluate different types of learning and knowledge environments. 
It is no wonder that a prior learning e-portfolio moves us toward a future in which we reach for "The spreading wide my narrow Hands-to gather Paradise" (Johnson, 1961, p. 657), or if not paradise then the endless possibility of personal, professional, and lifelong diverse modes of expressing PLAR “at our fingertips” through ICTs. 


\section{References}

Argyris, C., \& Schön, D. A. (1978). Organizational learning: A theory of action perspective. San Francisco: Jossey-Bass.

Artino, A. R. Jr. (2008). A brief analysis of research on problem-based learning. Retrieved from http://www.eric.ed.gov/ERICWebPortal/search/detailmini.jsp? nfpb=true\&_\&ER ICExtSearch_SearchValue_0=ED501593\&ERICExtSearch_SearchType_0=no\&a cCno=ED501593.

Baker, R. J., \& Kolb, D. A. (1990). Learning style exercise. Boston: McBer \& Company.

Baskin, P. (18 April 2008). Electronic portfolios may answer call for more accountability. The Chronicle of Higher Education, 54(32), A30-A31.

Billet, S. (2008). Learning through work: Exploring instances of relational interdependencies. International Journal of Educational Research, 47(4), 232-240.

Boud, D. (1993). Experience as the base for learning. Higher Education Research and Development, 12(1), 33-44.

Brown, J. O. (2000). The portfolio: A reflective bridge connecting the learner, higher education and the workplace. The Journal of Continuing Higher Education, 49(2), 1-13.

Brown, J. O. (2002). Know thyself: The impact of portfolio development on adult learning. Adult Education Quarterly, 52(3) 228-245.

Brown, J. O. (2005). The portfolio. In Leona M. English (Ed.), International Encyclopedia of Adult Education (pp. 485-489). Basingstoke, UK: Palgrave MacMillan.

Brown, J. O., McCrink, C., \& Maybee, R. (2004). Beyond college credits: How experiential learning portfolios foster adult students' personal and professional competencies and development. The Journal of Continuing Higher Education, 52(3), 24-35.

Choi, J., \& Hannafin, M. (1995). Situated cognition and learning environments: Roles, structures and implications. Educational Technology, Research and Development, 43(2), 53-69.

Cross, K. P. (1991). The adult learner. San Francisco. Jossey-Bass.

Dinevski, D., \& Psunder, M. (2005). Teacher development for lifelong learning. In A. Szucs \& I. Bo (Eds.), European Distance and E-Learning Network Annual Conference Proceedings (pp. 394-399). Budapest: University of Technology and Economics.

Ellstrom, E., Ekholm, E., \& Ellstrom, P. (2008). Two types of learning environments: Enabling and constraining a study of care work. Journal of Workplace Learning, 20(2), 84-97. 
European Distance and E-Learning Network (EDEN). (2007). Annual Conference Proceedings. Naples, Italy.

Evans, N. (Ed.) (1999). Experiential learning around the world. London: Jessica Kingsley Publishers.

Flint, T. (1999). Prior learning assessment: A status report. Assessment and Accountability Forum, 1(9), 15-16, 19.

Gergen, K. J. (1999). An invitation to social construction. Thousand Oaks, CA: Sage Publications.

Herman, C., \& Kirkup, G. (2008). Learners in transition: The use of eportfolios for women returners to science, engineering and technology. Innovations in Education and Teaching Technology, 45(1), 67-76. Retrieved from http://portfolio.psu.edu/.

Johnson, T. (Ed.). (1961). The complete poems of Emily Dickinson. Boston: Little, Brown.

Kolb, D. (1984). Experiential learning: Experience as the source of learning and development. Englewood Cliffs, NJ: Prentice-Hall.

Lave, J., \& Wenger, E. (1991). Situated learning. New York: Cambridge Press.

Maloney, E. J. (January, 2007). What web 2.0 can teach us about learning? The Chronicle of Higher Education: Information Technology, B26-B27.

Marsick, V. J. (1990). Action learning and reflection in the workplace. In J. Mezirow (Ed.), Fostering critical reflection in adulthood: A guide to transformative and emancipatory learning (pp. 23-46). San Francisco: Jossey-Bass.

Mezirow, J. (1996). Contemporary paradigms of learning. Adult Education Quarterly, 46, 158 173.

Michelson, E., \& Mandell, A. (2004). Portfolio development and the assessment of prior learning. Sterling, VA: Stylus.

Schön, D. A. (1983). The reflective practitioner: How professionals think in action. New York: Basic Books.

Sheckley, B. G., \& Keeton, M. T. (2001). Improving employee development: Perspectives from practice and research. Bloomington, IN: $1^{\text {st }}$ Books Library.

Slaatto, T. (2005). E-portfolio: A beneficial tool to develop digital culture to activize and involve citizens in digital learning activities. Paper presented at the European Distance and E-Learning Network (EDEN) Annual Conference, Helsinki, Finland. 
Timmons, F. (2008). Making sense of portfolios: A guide for nursing students. England: Open University Press.

Tynjala, P. (2008). Perspectives in workplace learning. Educational Research Review, 3(2), 130 154. 


\section{Appendix A}

Pre- and Post- First Pilot ELEP Surveys, $N=10$

Pre-Test ELEP Pilot 1 Technical Skills Survey of Student Participants

Using the scale below, rate your current ability with the following:

Post-Test ELEP Pilot 1 Technical Skills Survey of Student Participants

Using the scale below, rate your current ability after e-portfolio completion with the following:

$1=$ None $; 2$ = Poor $; 3=$ Fair $; 4=$ Good $; 5=$ Excellent

1. Using Microsoft Word

2. Using Microsoft PowerPoint

3. Using Microsoft Excel

4. Using the World Wide Web

5. Using/inserting video in a Word or PowerPoint document

6. Inserting graphics such as photos/clip Art in a Word/PowerPoint document

7. Creating hyperlinks in a Word/ PowerPoint document

8. Creating and inserting videos in a Word/PowerPoint document

9. Saving/burning documents to a CD

10. Scanning documents

$\begin{array}{lllll}1 & 2 & 3 & 4 & 5 \\ 1 & 2 & 3 & 4 & 5 \\ 1 & 2 & 3 & 4 & 5 \\ 1 & 2 & 3 & 4 & 5 \\ 1 & 2 & 3 & 4 & 5\end{array}$

$\begin{array}{lllll}1 & 2 & 3 & 4 & 5 \\ 1 & 2 & 3 & 4 & 5\end{array}$

$\begin{array}{lllll}1 & 2 & 3 & 4 & 5\end{array}$

$\begin{array}{lllll}1 & 2 & 3 & 4 & 5 \\ 1 & 2 & 3 & 4 & 5\end{array}$

Pre-Test ELEP Pilot 1 Professional Skills Survey of Student Participants

Using the scale below, rate your current perception of the following:

Post-Test ELEP Pilot 1 Professional Skills Survey of Student Participants

Using the scale below, rate your current perception after e-portfolio completion of the following:

1 = Strongly Disagree $; 2$ = Disagree $; 3=$ Somewhat Agree $; 4=$ Agree $; 5=$ Strongly Agree 
11. I have a good understanding of my $\quad \begin{array}{llllll}1 & 2 & 3 & 4 & 5\end{array}$ professional accomplishments

12. I have pride in my professional $\quad \begin{array}{llllll}1 & 2 & 3 & 4 & 5\end{array}$ achievements

13. I have a good understanding of the role $\quad \begin{array}{llllll}1 & 2 & 3 & 4 & 5\end{array}$ of work in my career development

14. I have a good understanding of how the $\quad \begin{array}{llllll}1 & 2 & 3 & 4 & 5\end{array}$ value of work experiences promote to learning

15. My understanding of my work accomplishments $\quad \begin{array}{llllll}1 & 2 & 3 & 4 & 5\end{array}$ helps me plan my future career goals

16. I recognize the role of mentors in my career $\quad \begin{array}{llllll}1 & 2 & 3 & 4 & 5\end{array}$

17. I understand the role of work in my adult $\quad \begin{array}{lllllll}1 & 2 & 3 & 4 & 5\end{array}$ development

18. I recognize the value of past/present community $\quad \begin{array}{lllllll}1 & 2 & 3 & 4 & 5\end{array}$ activities in learning

Pre-Test ELEP Pilot 1 Academic Competencies Survey of Student Participants

Using the scale below, rate your current perception of the following:

Post-Test ELEP Pilot 1 Academic Competencies Survey of Student Participants

Using the scale below, rate your current perception after e-portfolio development of the following after e-portfolio completion:

1 = Strongly Disagree; 2 = Disagree $; 3$ = Somewhat Disagree; 4 = Agree; 5 = Strongly Agree

19. I have highly developed written communication skills

20. I have highly developed critical thinking skills

21. I have highly developed organizational skills

22. I have highly developed reflection skills

23. I have a great deal of self-knowledge

24. I have a good deal of self-esteem

25. I have a good deal of self-confidence

$\begin{array}{lllll}1 & 2 & 3 & 4 & 5 \\ 1 & 2 & 3 & 4 & 5 \\ 1 & 2 & 3 & 4 & 5 \\ 1 & 2 & 3 & 4 & 5 \\ 1 & 2 & 3 & 4 & 5 \\ 1 & 2 & 3 & 4 & 5 \\ 1 & 2 & 3 & 4 & 5\end{array}$




\section{Appendix B}

ELEP First Pilot Participants Pre-Test Survey Results, $N=10$

\begin{tabular}{|l|l|l|l|l|l|}
\hline & $\begin{array}{l}5= \\
\text { Excellent }\end{array}$ & $4=$ Good & $3=$ Fair & $2=$ Poor & $1=$ None \\
\hline Q \#1 & $30 \%$ & $40 \%$ & $30 \%$ & $0 \%$ & $0 \%$ \\
\hline Q \#2 & $10 \%$ & $60 \%$ & $20 \%$ & $10 \%$ & $0 \%$ \\
\hline Q \#3 & $20 \%$ & $40 \%$ & $30 \%$ & $10 \%$ & $0 \%$ \\
\hline Q \#4 & $30 \%$ & $60 \%$ & $0 \%$ & $10 \%$ & $0 \%$ \\
\hline Q \#5 & $0 \%$ & $20 \%$ & $40 \%$ & $30 \%$ & $10 \%$ \\
\hline Q \#6 & $30 \%$ & $50 \%$ & $0 \%$ & $20 \%$ & $0 \%$ \\
\hline Q \#7 & $20 \%$ & $10 \%$ & $40 \%$ & $30 \%$ & $0 \%$ \\
\hline Q \#8 & $0 \%$ & $10 \%$ & $50 \%$ & $30 \%$ & $10 \%$ \\
\hline Q \#9 & $10 \%$ & $40 \%$ & $40 \%$ & $10 \%$ & $0 \%$ \\
\hline Q \#10 & $20 \%$ & $40 \%$ & $30 \%$ & $10 \%$ & $0 \%$ \\
\hline & $5 \%$ & & $3=$ & & 1 \\
& Strongly & & Somewhat & $2=$ & Strongly \\
\hline Agree & $4=$ Agree & Disagree & Disagree & Disagree \\
\hline Q \#11 & $50 \%$ & $40 \%$ & $0 \%$ & $10 \%$ & $0 \%$ \\
\hline Q \#12 & $60 \%$ & $30 \%$ & $10 \%$ & $0 \%$ & $0 \%$ \\
\hline Q \#13 & $40 \%$ & $50 \%$ & $10 \%$ & $0 \%$ & $0 \%$ \\
\hline Q \#14 & $70 \%$ & $20 \%$ & $10 \%$ & $0 \%$ & $0 \%$ \\
\hline Q \#15 & $60 \%$ & $30 \%$ & $10 \%$ & $0 \%$ & $0 \%$ \\
\hline Q \#16 & $50 \%$ & $30 \%$ & $20 \%$ & $0 \%$ & $0 \%$ \\
\hline Q \#17 & $60 \%$ & $30 \%$ & $10 \%$ & $0 \%$ & $0 \%$ \\
\hline Q \#18 & $50 \%$ & $30 \%$ & $20 \%$ & $0 \%$ & $0 \%$ \\
\hline Q \#19 & $20 \%$ & $30 \%$ & $40 \%$ & $10 \%$ & $0 \%$ \\
\hline Q \#20 & $50 \%$ & $10 \%$ & $40 \%$ & $0 \%$ & $0 \%$ \\
\hline Q \#21 & $60 \%$ & $30 \%$ & $0 \%$ & $10 \%$ & $0 \%$ \\
\hline Q \#22 & $30 \%$ & $50 \%$ & $20 \%$ & $0 \%$ & $0 \%$ \\
\hline Q \#23 & $30 \%$ & $50 \%$ & $10 \%$ & $0 \%$ & $0 \%$ \\
\hline Q \#24 & $40 \%$ & $20 \%$ & $40 \%$ & $0 \%$ & $0 \%$ \\
\hline Q \#25 & $30 \%$ & $40 \%$ & $30 \%$ & $0 \%$ & $0 \%$ \\
\hline & & & & & \\
\hline & & & $0 \%$ & $0 \%$ \\
\hline
\end{tabular}




\section{Appendix C}

ELEP First Pilot Participants Post-Test Survey Results, $N=10$

\begin{tabular}{|l|l|l|l|l|l|}
\hline \multicolumn{2}{|c|}{$5=$ Excellent } & $4=$ Good & $3=$ Fair & $2=$ Poor & $1=$ None \\
\hline Q \#1 & $50 \%$ & $40 \%$ & $10 \%$ & $0 \%$ & $0 \%$ \\
\hline Q \#2 & $30 \%$ & $50 \%$ & $20 \%$ & $0 \%$ & $0 \%$ \\
\hline Q \#3 & $40 \%$ & $40 \%$ & $10 \%$ & $10 \%$ & $0 \%$ \\
\hline Q \#4 & $70 \%$ & $10 \%$ & $20 \%$ & $0 \%$ & $0 \%$ \\
\hline Q \#5 & $20 \%$ & $20 \%$ & $40 \%$ & $10 \%$ & $0 \%$ \\
\hline Q \#6 & $70 \%$ & $10 \%$ & $20 \%$ & $0 \%$ & $0 \%$ \\
\hline Q \#7 & $50 \%$ & $40 \%$ & $10 \%$ & $0 \%$ & $0 \%$ \\
\hline Q \#8 & $10 \%$ & $30 \%$ & $40 \%$ & $10 \%$ & $0 \%$ \\
\hline Q \#9 & $50 \%$ & $40 \%$ & $10 \%$ & $0 \%$ & $0 \%$ \\
\hline Q \#10 & $70 \%$ & $30 \%$ & $0 \%$ & $0 \%$ & $0 \%$ \\
\hline & & & $3 \%$ & & \\
& $5=$ Strongly & & Somewhat & $2=$ & $1=$ Strongly \\
\hline Q \#11 & $50 \%$ & $4=$ Agree & Disagree & Disagree & Disagree \\
\hline Q \#12 & $80 \%$ & $50 \%$ & $0 \%$ & $0 \%$ & $0 \%$ \\
\hline Q \#13 & $60 \%$ & $20 \%$ & $0 \%$ & $0 \%$ & $0 \%$ \\
\hline Q \#14 & $80 \%$ & $40 \%$ & $0 \%$ & $0 \%$ & $0 \%$ \\
\hline Q \#15 & $70 \%$ & $20 \%$ & $0 \%$ & $0 \%$ & $0 \%$ \\
\hline Q \#16 & $60 \%$ & $20 \%$ & $10 \%$ & $0 \%$ & $0 \%$ \\
\hline Q \#17 & $60 \%$ & $30 \%$ & $10 \%$ & $0 \%$ & $0 \%$ \\
\hline Q \#18 & $45 \%$ & $30 \%$ & $10 \%$ & $0 \%$ & $0 \%$ \\
\hline Q \#19 & $40 \%$ & $55 \%$ & $0 \%$ & $0 \%$ & $0 \%$ \\
\hline Q \#20 & $50 \%$ & $50 \%$ & $0 \%$ & $0 \%$ & $0 \%$ \\
\hline Q \#21 & $60 \%$ & $40 \%$ & $0 \%$ & $0 \%$ & $0 \%$ \\
\hline Q\#22 & $60 \%$ & $40 \%$ & $0 \%$ & $0 \%$ & $0 \%$ \\
\hline Q \#23 & $50 \%$ & $50 \%$ & $0 \%$ & $0 \%$ & $0 \%$ \\
\hline Q \#24 & $40 \%$ & $60 \%$ & $0 \%$ & $0 \%$ & $0 \%$ \\
\hline Q \#25 & $40 \%$ & $60 \%$ & $0 \%$ & $0 \%$ & $0 \%$ \\
\hline & & & & $0 \%$ & $0 \%$ \\
\hline
\end{tabular}




\section{Appendix D}

\section{ELEP Second Pilot Post (No Pre-Questionnaire) ELEP Questionnaire Responses}

Thank you for your participation in our second ELEP pilot. Your participation has provided valuable information and insight into our program. To provide further understanding from a student's perspective and in order to assist subsequent ELEP students better, we are asking you to take a few minutes to complete the following questionnaire.

1. What value, if any, did the electronic version add to your Portfolio experience?

$>$ It enhanced my PowerPoint presentation skills.

$>$ It was truly a wonderful experience! Not only did I update my PowerPoint skills, but it is nice to have all of my important documents in an electronic presentation format.

$>$ I was able to be more imaginative with the PowerPoint presentation, so more of me came out.

2 Why did you choose to complete the electronic format instead of the paper-based format?

$>$ I think the electronic format is more creative and is interesting.

$>$ I liked the fact that you could really make this your own, unique presentation versus the paper format that limited my creativity to some degree.

$>$ I felt that it would be easier for me with my IT background, and I did not want to kill a couple of trees to complete my project.

3. Please indicate $(\mathrm{X})$ the materials you utilized during your ELEP development/completion process and circle or indicate your level of satisfaction for each.

Scale = Strongly Satisfied; Satisfied; Dissatisfied; Strongly Dissatisfied; N/A
a. Portfolio Module Guide
$\begin{array}{ll}\text { Strongly Satisfied } & 2=66.7 \% \\ \text { Satisfied } & 1=33.3 \% \\ \text { Strongly Satisfied } & 2=66.7 \% \\ \text { Satisfied } & 1=33.3 \%\end{array}$
b. Technical Module
$2=66.7 \%$
c. Julia Winthrop Sample - paper-based
Strongly Satisfied
$1=33.3 \%$
d. Julia Winthrop Sample - CD
Satisfied
$3=100.0 \%$
e. Blackboard (Course Tools)
Strongly Satisfied
$2=66.7 \%$
Strongly Satisfied
$1=33.3 \%$
i. Announcements
Satisfied
$2=66.7 \%$
Strongly Satisfied
$1=33.3 \%$
ii. Samples
Satisfied
$2=66.7 \%$
Strongly Satisfied
$1=33.3 \%$
iii. Technical Manual
Satisfied
$2=66.7 \%$
Strongly Satisfied
$1=33.3 \%$ 


$\begin{array}{lll}\text { iv. Calendar } & \text { Strongly Satisfied } & 2=66.7 \% \\ & \text { Satisfied } & 1=33.3 \% \\ \text { v. Discussion Board } & \text { Strongly Satisfied } & 1=33.3 \% \\ & \text { Satisfied } & 1=33.3 \% \\ \text { Ni. Questions for the Moderators } & \text { Strongly Satisfied } & 1=33.3 \% \\ & \text { Satisfied } & 1=33.3 \% \\ \text { Nii. Comments \& Suggestions } & \text { Strongly Satisfied } & 1=33.3 \% \\ & \text { Satisfied } & 1=33.3 \% \\ \text { viii.Contact Us } & \text { N/A } & 1=33.3 \% \\ & \text { Strongly Satisfied } & 2=33.3 \% \\ \text { ix. Individual Folders } & \text { Satisfied } & 1=33.3 \% \\ & \text { Strongly Satisfied } & 2=66.7 \% \\ \text { x. Other ( } & \text { Satisfied } & 1=33.3 \% \\ & \text { Satisfied } & 1=100.0 \%\end{array}$

f. If you utilized the Technical Module

i. Were the instructions clearly written? Yes $\quad 3=100.0 \%$

ii. Were the instructions easy to follow? $\quad$ Yes $\quad 3=100.0 \%$

iii. Was there any missing material/instructions?Yes $1=33.3 \%$

No $\quad 2=66.7 \%$

If yes, please specify (no comments included)

g. If you utilized Blackboard, was there anything we could have developed differently?

$>$ Not at all—very helpful

$>$ None

$>$ I was trying to use the Blackboard site like a web class but did not see it utilized by the school very much.

h. What additional resources and materials do you think are necessary for the ELEP program?

$>$ None that I can think of at the moment

$>$ None

$>$ No comment included

4. What was the most helpful aspect of the current resources available to you?

$>$ The sample CD

$>$ Julia Winthrop Sample - CD

$>$ No comment included

5. What was the least helpful aspect of the current resources available to you?
$>\mathrm{n} / \mathrm{a}$
$>$ None 
The fact you had to make the attachment PDF. Not everyone has that capability and the software is expensive.

6. What technical skill level, if any, do you think a student needs in order to complete the ELEP?

$>$ A solid background in PowerPoint and an understanding of hyper linking

$>$ Computer skill is a must, especially familiarity with PowerPoint.

$>$ They should have Microsoft office and some web to develop the project fully.

7. What advice would you give to students interested in completing an ELEP?

$>$ I would say to follow the sample CD as closely as possible and touch base with your assigned IT personnel for any technical difficulties you may have.

$>$ They must have confidence in their computer skills before they choose to do an ELEP.

$>$ Go for it. I enjoyed the whole experience.

\section{Other Comments:}

$>$ The staff was very helpful and made the completion of my e-port a breeze...

$>$ It would be nice if we could have more space for creativity portfolio instead of following the format in the sample. You might want to reformat the LAW form. To my knowledge, all of us had trouble with the margin setting when we worked on the LAW form.

$>$ I enjoyed it; the whole experience was an eye opening experience. Thanks!

Thank you for your time and effort in completing this questionnaire and for your participation in our second ELEP pilot!

\section{Athabasca University $\mathbf{7}$}

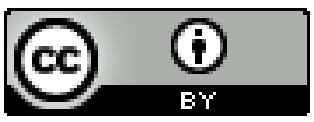

